\title{
Birds, Snakes, and Scarecrows: Waving Realities in Modern English Literature
}

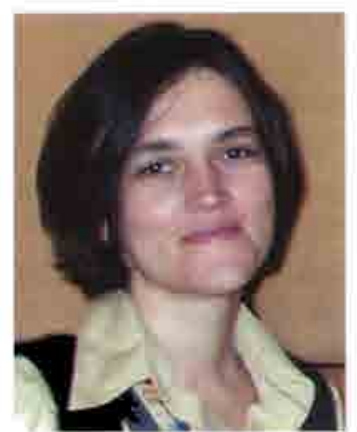

Marija Knežević

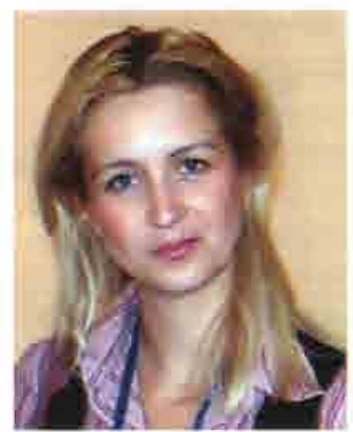

Aleksandra Nikčević-Batrićević

$\mathrm{T}$ his paper attempts an ontological reading of poetry, in which we have tried not only to stretch the border of literary modern (considered in its primary meaning as a reaction to positivist thought as well as a realist and naturalist art conception) further into the past and across literary figures discarded from the modern canon. Besides, with an aim to demonstrate the notion of triumphing "other" to be one of the core determinants of the nineteenth- and twentieth-century literary idiom, we are deliberately employing the ambiguous phrase "waving realities" that embraces as wide a semantic field as "gesticulating - shaking - flourishing," as contradictory literary stance as rejecting and, at the same time, accepting the surface reality, and as deep a historical dispute over the nominal vs. verbal existence of the text.

Contrasting Victorian images of the poet with those of the Romantics, Bernard Richards notices how " $[t]$ he Romantics could never decide whether or not a poet was born different from other men, but they were in no doubt that sustained development of habits and vision and modes of expression led to highly specialized ways of being," (17) whereas their successors could not claim such an ambitious stand due to the increasing power of science and utilitarianism that marginalized poetry as an ineffective expression of subjectivity. Still, we are of the opinion that a similar notion could be traced in the achievements of, more or less, all the coming generations of poets, however distant from the centre $f$ their time they may have been. Following these traces on the examples of distinct oetic sensibilities, Alfred Tennyson, William Butler Yeats, and D. H. Lawrence, we zalize that all of them found their raison d'être as poets in discovering ways to express, I Pope's famous phrase, "[w] hat oft was thought, but ne'er so well expressed," to find ew living forms of being and thus become "the unacknowledged legislators of the corld" - the romantic notion which Naill Lucy succeeds to stretch even to ostmodernity (1977). Besides, this unusual poetic triangle is united by a constant truggle with, what Nikolai Hartmann called (we are deliberately employing this most eneral division) Fordergrund, the outer, material aspect of the poem, or, in 
Baudrillard's terms, the perverting sign which determines the poem's transcendental and ideal background. Rejecting the positivist reifying relation with the universe, they believed that artistic creation is always revelatory, and, therefore, not only, in a broad anthropological sense, a religious act (Cf. Eliade 1972), but also an ontological act.

Moreover, this parallel concern is expressed in similar traditional imagery. In a symbolical and mythological sense birds have primarily represented a power that enables coherent speech and thought that precede act and have been regarded, therefore, as divine messengers. The first unavoidable association the snake makes in western symbolical imagery is that of the myth of the fallen angel. For being bound to the earth and frightening gravitational spheres, the realm of snake is also associated with the underworld, the world of the dead. In a larger perspective, "[1]inked to the freezing, clammy subterranean darkness of the beginning of things," (Dictionary of Symbols 845) the snake has been perceived as a slippery being that rejects western symbolical imagery and gives a feeling of "primordial formlessness." As such it is used in some modernist works as a symbol of incomprehensible outer otherness.'

Third, the seemingly comic, image of "a tattered coat upon a stick" perfects the feeling of human hopelessness to hold, once it glimpses, the compact wholeness of being, as is successfully presented by the cross, the axis of the world, where man stands open to the wonderful world of the divine other.

This endeavour to hold the fullness of reality in a work of art is succinctly expressed in D. H. Lawrence's idea of the poetry of the present. For him, the inherited imagery and forms can never hope to express what the attentive man discerns in the immediacy of his own poetic cosmos. Only in poetry which transcends linear projection of western thought and immerses in the resonant instant, can we read our own true being. To satisfy this deep ontological wish, poetry must be inconclusive, the "running water," "the unfinished tide," "the living plasm." (Lawrence 1993:182) Lawrence's is not an abstract concept; it understands that the poetic "bird" that gives birth to the poem comes from and settles back on a solid earth, but while it travels "the bird is on the wing in the winds" (183) and ungraspable. As such it reaches the sphere of sui generis, becoming a world true in itself yet always elusive. It always transcends temporal and spatial determinants, because, as Compagnon says, the act of consumption of a work of art, which is participation in the creation of truth, like all human experience, is unavoidably equivocal, ambiguous, torn between understanding and love, philology and allegory, freedom and restraints, attention to the other and care of one's own self. (Kompanjon 211)

When in the turbulent nineteenth century reality was believed to be the world as it appears to our visual perception, and, according to John Ruskin, aesthetic beauty had to be true to that reality, to be trustworthy an artist was expected to paint details of life's surface like a photographer. That such unselective mimesis was discouraging for an artist who was painfully aware of the rising incongruity between his inner self and the outer world, and therefore inadequacy of anthropomorphic language, and who knew that physical manifestation of the world depends on the onlooker ("It is the spectator and not life, that art really mirrors," says Oscar Wilde), proves the case of already most of the 
anthologized verses of Alfred Tennyson. For Tennyson, who felt himself a mystic excluded from the "narrower cycle" ("Mystic") of the everyday world, creating was transcending of the given, "Crossing the Bar," which, in his poem "Armageddon," is depicted as a supernatural process of intensified perception and understanding that, alas, does not only bind the poet alone, but also makes him aware that "Each sailing sense / As with a momentarily flash of light / [grows] thrillingly distinct and keen." The inescapable experience of fleetingness of revelation may have caused a deep frustration and melancholia that coloured, it seems, Tennyson's response to creating poetry. If we translate Lawrence's metaphor of the unfinished tide into Tennyson's language, it will read as a momentary step over the threshold of fantasy onto immensity of the unbroken deeps:

\section{But such a tide as moving seems asleep, Too full for sound and foam, When that which drew out of the boundless deep Turns again home}

When the image of the fullness and self-sufficiency of the tide is about to perfect itself, having united the ideal and material aspects of the verse, it only crumbles into its separate unites, and is turned home or dispersed. What adds to the representative quality of these verses is the unity of their rhythmic and visual aspects that, as David Morse notices, often resembles a frustrated dream movement (249-260). Even in one of Tennyson's most dynamic poems, "Ulysses", the summit of the dramatic moment is reached in a vision of a ship that puffs its sails but stays in the port without completing the action. As if the "recklessly speculative age" in which he was forced to create, forced him also, looking for a truer reality and baring layers of unconquerable language, to create poetry of a prolonged pain, as is that of the ever shrivelling Tithonus beside the vain, ever renewing beauty of Aurora, of the growing curse of death in life upon the moated grange in "Mariana" that never really reaches its climax but retreats back into the endless agonizing cycle of solipsism and loneliness, of the receding vague images of happiness brought about by the idle tears and the despair of a dying man who as if for the first time, and only for a fleeting moment, hears the "fresh and strange" song of "half-awakened birds." (Tennyson 238) Finally, prolonging the distressing loss in In Memoriam, the poet is crushed by sudden realization that to be so "blessed" as to possess pure faith that "has centre everywhere," (303) in life and love, is not possible in the age of his. The earth he inhabits, which to "some wild poet, when he works / Without conscience or aim" (304) is the "round of green, this orb of flame, / Fantastic beauty," devoid of faith becomes "darkness at the core." Therefore, if there were not any higher purpose to this life, if God bequeathed the poet but "to choose / Of things all mortal," he must "use a little patience," i.e. rely on his virtuosity, "ere I die," he says. As irony doesn't become Tennyson, he understands that if only his death would render his art transcendent of the boundaries of matter, 


\section{'Twere best at once to sink to peace \\ Like birds the charming serpent draws, To drop head-foremost in the jaws \\ Of vacant darkness and to cease.}

Although for a moment the image gives an impression of a completed action, it also forces us to return to its conditional beginning. To this seeming cessation Tennyson gave another image in "Lady of Shalott." Like the lady, who, accursed to life of shadows in a forsaken tower, loses life once she decides to disregard the curse and cause the mirror, out of whose reflection she waves a tapestry, to break, so must the poet live within his "Palace of Art" or else die having sung his best song. Only in this restless, everlasting, though "damned vacillating state," ("Supposed Confessions," Tennyson 17) this oscillating between the world of everyday and that of a mystic, and the images of his imagination, could he achieve his being as a poet. For him, as yet, no creation is absolute, while he, as a biological being founded in a cultural space, exists.

This notion may also be read in Yeats's splendid image of transfiguring dance, which is inseparable from the dancer although it enables the dancer (that shapes the end of "Among School Children"), or in his "Cuchulian's Fight with the Sea" that can be ended only if Cuchulian dies or the sea runs dry. These examples show that there is always an unending exchange of vital impulses between the artistic images and the poetical being. The broken ladders of inspiration, in "The Circus Animals' Desertion," that leave the "foul rag and bone shop of the heart" (Yeats 2000: 224) at their bottom also demonstrate that the poet cannot think about himself as a poet without the images from his imagination. Besides, they are neither political nor purely aesthetical, but living entities that enable new ways of self-awareness, transcending not only particular temporal and spatial but also mythical boundaries, and rendering the poet's art naked of these coats, cool, dumb, deaf as a fish ("Politics"). It is poured out of the author's struggle to reach divine wonders into material immediacy, wrapped in his direct and simple language of a mystic, and given a living form. This means that the living realms of life are only those invested with vitality of a passionate man, but which, reciprocally, enable other ontological spheres. Therefore, if, for Yeats, an ideal cosmos is discerned in eternal becoming, Byzantium can always be. In Byzantium of Yeats's imagination, diverse aspects of religious, aesthetic, and practical life are imbued with art, infused by living impulses of craftsmen who, having transcended individual design have, in turn, become absorbed into the permanence of art. Yet, the riddle of how a mortal being is to achieve this perfection in the now of his own, Yeats tries to solve in "Sailing to Byzantium."

Employment of gerundive construction in the title that gives substance to the metaphorical journey and suggests infinite progression towards the realm of imagination, suggests transcending of the material rootedness as the primary source of intimidation for the singing soul. Yet, the "tattered coat upon a stick" (128) is not only the poet's aged body, but also a ready-made image from cultural inheritance we find in "Among School Children," where the "[o]ld clothes upon a stick to scare a bird" (153) is a reflection of the three philosophical systems: Plato's, Aristotle's and Pitagora's. 
Besides, in the triangular mirror of this quester's mind, they are also the "self-born mockers of man's enterprise," abstract and untouchable. When in this poem of completeness, the poet finds the body of the mythic Leda for his unrequited though greyhaired love, he also admits that while he never managed to ascend the throne of Zeus, he did have "pretty plumage once," (152) the complex relationship of one's past and present reaches climax. When in "Sailing" he pronounces that this young bird, belonging to "dying generations," is frightened of mortality, he does not, as often believed, confute Keats's "immortal Bird," but suggests that he has found the way to scare off the fright. As Anthony L. Johnson (in Staton 137) rightfully notices, clasping hands is yet another way to scare a bird, it is exactly when the poem says "unless soul clasps its hands and sing, and louder sing for every tatter in its mortal dress" (128) that the contradictory principles meet in the experienced craftsmanship, which is transcendent of the mortal fear. Having acknowledged this clasping hand as the creative movement that shapes our inner life, and indeed perfects the spirit as the spirit perfects it, the poet gains grounds for specific poetical self-transcendence.

Although a poet is always a part of the inheritance, imaginative and psychological history, for Yeats, he/she is also an intention. In "A General Introduction for my Work," he says that a poet is "never the bundle of accident and incoherence that sits down to breakfast; he has been reborn as an idea, something intended, complete." (Yeats 1937: 509) Actually, a poet is "an artificial construction or concept [...] the result of deliberate act of poetic imagination," (Web in Yeats 2000: xxi) while his "poetic identity which is achieved with increasing precision," may be "rendered absolute only by his death." (xxvii) In this way, construing his own poetical supernatural transformation, Yeats reaches the icons of the old Byzantium masters that can teach him to "perne in a gyre," (128) which is another image of the never-ending process in which the movement and the thread become indiscernible to the naked eye, and turn "into the artifice of eternity." Byzantium now surfaces from the layers of historical and linguistic consciousness as an existential, historical, and artistic eternal realm. Therefore it gives enough space to the poet to envisage his next incarnation, abstracted from the fires of creation, not really in another biological, but into another physical palpable being, the undying artificial golden bird, that will sit on the golden bough and sing to the nobility of Byzantium of "what is past, or passing, or to come," i.e. of transience. At this moment, journeying above the temporal immediacy, and reaching the poetic absolute in the golden bird, the poet has come to an ecstatic and paradoxical moment of artistic creation - creating he creates himself and always transcends himself. As in his last letter, dated January 4 1939, Yeats remarked that "[m]an can embody truth, but he cannot know it," when the golden bird brings the eternal coming and passing into play, it is instantly ironically transcended with the seesaw image of a drowsy emperor, which is that slippery step the poem risks to reach the trembling balance of instability, which, for D. H. Lawrence, is the primary condition of an aesthetic moral, and which in its truest core is the artifice.

Finally, approaching Heidegger's ideal of poetry whose tasks is to "fill our thoughts with the essence of things, and not with things," their mere beauty or instrumentality, Yeats builds quick images of reintegration, where "blood, imagination, intellect [are] 
running together," as final transfigurments of content and form, gesticulating movements not only to an ideal which they are to embody but also to the material signs employed in their creation. Although he talks of a passionate energy, his concern for a balance and, indeed, his insistence on artifice by which life is transformed into art, which Timothy Web calls Yeats's "ironical insistence on the unromantic," (in Yeats 2000: xxiv), produces traditionally formal verses, obvious in the perfect structure of the four eight-line stanzas of "Sailing to Byzantium," developed in iambic pentameter and ABABABCC rhyme.. When Yeats says that "[a]ncient salt," i.e. the traditional stanza and classical discipline, "is best packing," he may be endeavouring to give shape to the chaotic surrounding of his time, but also expressing delight of the accomplished master in verse.

The idea that art is a divination into the unknown often made D. H. Lawrence stand agape before the phenomenal world, endeavouring to avoid the weakness of solipsism. He was not romantic but bitterly aware that he cannot fight human inheritance to meet his goals. Therefore, for Lawrence, if a "whole man alive" truly attends the otherness perceived, his art will witness his endeavours, demonstrating the poet's "struggle with his conscious being." For this reason he is called "a poet without a mask." (Pinto and Roberts 1)

The snake which appears in Lawrence's poem "Snake" is not imaginary but a real being, an ordinary Sicilian viper that happened in front of him at his water-trough on a hot July day in Taormina. Seeing the snake has come first to the water, the poet waits "in the deep, strange-scented shade of the great dark carob-tree," (Lawrence 1993: 349) a silent place which does not only give shelter from the heat but, with a slight tone of strangeness and freshness, becomes a strong reminiscence of Eden. Lawrence's choice, and, actually, creation of attributes to the snake's trailing movement, in "his yellow-brown slackness soft-bellied down," is richly mimetic and evocative of the surrounding geography. As the movement seems intentional, the poet imagines the snake a persona, a "someone", a possible collocutor, and, finally, the peer of the realm, "Like a king in exile, uncrowned in the underworld," that for a moment he is charmed by the look of this strange presence, which to him is still unreadable, "vague." Soon his consciousness creates unavoidable association of the dark charmer, coming from the fires of the underworld - "Being earth-brown, earth-golden from the buming bowels of the earth," which image is grounded in the nearby active Etna, and hears the voices of his Christian and male education trying to persuade him to kill the snake, because it is repulsive and venomous: "And voices in me said, If you were a man / You would take a stick and break him now, and finish him off." (350) Yet, as he knows that these are seldom life-affirming voices, the snake of "the secret earth" becomes manifestation of the rising tide of libido, embodiment of the procreative powers man has been unnaturally taught to fear and despise. Therefore, his infatuation with the slimy curvy creature with flickering tongue, "like a forked night on the air, so black," he deems, may be read as fear or perversity, whose notion also embodies Lawrence's constant, maybe obstinate, image of an outsider.

The poet's struggle to elude cultural determinants turns the snake into a mythological noble being, like that, as Sandra Gilbert shows, from Blake's vision (174), which, moreover, evokes the reptilian images from Lawrence's other works, Egyptian 
Uraeus, Asiatic Kundalini, Aztec Quetzalcoatl'2.

Yet the complex intertextual net allows the implied drama to deepen from the mere dialogue between the murderous cultural voices and the spontaneous natural being towards more disturbing notions. For its power to renew its skin and deliver eggs, like a bird, for its ability to transform from male to female appearance, the snake does not only give special impetus to the treatment of blind sexual instinct but must also embody dangerously ambiguous state, reflecting the inner drama that is taking place within the poetical persona who, at the moment of creation, is transcended into a creative subject neither male nor female, neither born nor yet dead. What happens next is a painful disillusionment of which Lawrence talks in his metaphysical essay Apocalypse:

We always want a 'conclusion', an end, we always want to come, in our mental processes, to a decision, a finality, a full stop. This gives us a sense of satisfaction. All our mental consciousness is a movement onwards, a movement in stages, like our sentences, and every full stop is a mile-stone that marks our 'progress' and our arrival somewhere. On and on we go, for the mental consciousness. Whereas of course there is no goal. Consciousness is an end in itself. We torture ourselves getting somewhere, and when we get there it is nowhere, for there is nowhere to get to. (50)

In this poem, once the snake averts his eyes and, "snake-easing his shoulders," (Lawrence 2000: 351) retreats into the earth, as if its charm collapses and the scene inverses. The hole of its retreat becomes "that dreadful hole," "that horrid black hole," in the wall which is now "my wall-face," "the earth-lipped fissure" as if of a humaneating devil. The same horrifying solipsism may have overcome the onlooker that he feels cheated, so that he "picked up a clumsy log / And threw it at the water-trough with a clatter," breaking the charm. Although he does not hit the snake, he frightens him so that "suddenly that part of him that was left behind convulsed in undignified haste," being finally rendered repulsive. In the end, the poet regrets his inability to hold the present of the pure vivid life, thinking "how paltry, how vulgar, what a mean act!" he has performed. The snake now becomes "the albatross," the killed bringer of good, and "my snake," i.e. the poet's source of unending regret.

As it is only honest in a work that looks for a possibility of achieving his poetic identity beyond culture, the final message of the snake is always "deflected and delayed." (Chaudhuri 13) In this sense, comparing the voice of Lady Macbeth with that of the narrator's education, Chaudhuri assumes another "dramatic boundary around the text of 'Snake', which enables us to hear false notes in it." (18) Namely, King Duncan comes to Macbeth's castle as the snake comes to Lawrence's garden as a 'king' and guest in peace, but also as his murderer's guest. Another word which strikes similarity is "honour" which occurs in Lawrence's ambiguous line "Was it humility to feel so honoured? / I felt so honoured." (Lawrence 2000: 350) In connection with Macbeth where "the use of the word [by Duncan and Lady Macbeth] is either tragically unsuspecting or ironically sinister," Lawrence's expression becomes "immediately tainted." (Chaudhuri 17) As Lady Macbeth has two voices, one to celebrate the king and the other to plot his murder, the speaker in "Snake" voices both celebration and 
aggression and in this light the voices present in the poem can no longer be seen as engaged in a dialogue between the natural and civilized voices, but in a more conspiring relationship, when the poet's voice suggests "dissimulation, of being as much party to the act of murder as the voice that blatantly encourages it, and all the more dangerous for being disguised, falsely "poetic' voice." (18)

Apart from this, an interesting echo of Milton's sonnet "" is recognized by Ian Lancashire. In his view "Milton alludes to the parable of the talents [...] in which Jesus likens the kingdom of heaven to a man who, like God, gives talents to his servants and expects them to use them and make them grow," whereas those afraid to do so are cast out into the darkness of hell. According to Lancashire, the speaker's anguish in "Snake" likewise comes from cowardice. When he casts the gift from the Lord of Life, scaring him back into earth, he is terrified "that he would fail by losing the lord's talent entirely," and therefore must "expiate" for his "pettiness." (2)

In the end, as Chaudhuri observes, the inconclusiveness of Lawrence's text makes us feel as if we, "had gained access to the stage after the show was over and the hall empty, and witnessed, to our delight and disconcertment, the props and the bits of wood and cloth and string out of which that enchantment and that spectacle of movement and life had been constructed, now lying arbitrarily upon the floor." (Chaudhuri 82) This collapsing image inevitably reminds us of the closing image in Yeats's "The Circus Animals' Desertion." Yeats's poem that opens regretting loss of inspiration actually ends in gratification that it is able to confess a delicate turn from the "comfortable old smiling scarecrow" (Yeats 2000: 152) into the "foul rag and bone shop of the heart" that lies at the bottom of his now tumbled-down poetical ladders. While Milton's sonnet asserts patience, as Tennyson supposed a poet should patiently rely on his virtuosity, the snake, a slippery being the poet fails to hold, resembles challenge of the elusive poetical language. Indeed, the language of this poem, the manipulation of the free verse, which, as Keith Sagar suggests, shapes structure mimetic of snake's movement, with its "sibilant, slithering alliterative s's, the slack undulating rhythms," (Sagar 121) paradoxically shows Lawrence not a poet without a mask but a cunning versifier. Maybe for this reason that at the end of "Snake," when the poet does not wait in patience any longer, he throws a log at his own face, attempting to finally break the reflecting mirror of his persona, as Tennyson did in "Lady of Shallot", and commit a poetical suicide.

Maybe he is disillusioned, aware of the fact that this ideal instant of present is a fallacious and non-existential moment, a mere projection of a past intention or a future regret, in which, therefore, everything can be read, as Philip Larkin suggests looking from his High Windows onto the youth on the street who may "all go down the long slide / Like free bloody birds," but actually remind bound to the earth, because the sky, "the deep blue air [...] shows / Nothing, and is nowhere, and is endless." (2366)

\section{Notes:}

1. Exp. the reptile image dominates in J. Conrad's, D. H. Lawrence's, E. M. Forster's perceptions of the foreign places.

2. Cf. Lawrence, Apocalypse and The Plumed Serpent. 


\section{References:}

1. Chaudhuri, A. (2003) D. H. Lawrence and 'Difference'. Oxford: Clarendon.

2. (1996) Dictionary of Symbols. London: Penguin.

3. Eliade, M. (1972) La Sacré et le Profane. Paris: Gallimard.

4. Gilbert, S. (1972) Acts of Attention. New York: Cornell UP.

5. Kompanjon, A. (2001) Demon teorije. Tr. by M. Kozić, V. Kapor, B. Rakić. Novi Sad: Svetovi.

6. Lancashire, I. (2007) Snake, 2005, http://www.quazen.com/Arts/Literature/Snake-by-DH-Lawrence.36418, 11:30, August 4.

7. Larkin, Ph. (1986) High Windows // The Norton Anthology of English Literature. New York - London: Norton, pp. 2365-2366.

8. Lawrence, D. H. (1980) Apocalypse. With and Introduction by Richard Aldington. Harmondsworth - London: Penguin - Heinemann.

9. Lawrence, D. H. (1993) Complete Poems / Ed. by Vivian de Sola Pinto and Warren Roberts. Harmondsworth: Penguin.

10. Lucy, N. (1977) Postmodern Literary Theory: An Introduction. Blackwell.

11. Morse, D. (1993) High Victorian Culture. London: MacMillan.

12. Richards, B. (1988) English Poetry of the Victorian Period (1830-1890). New York: Longman.

13. Sagar, K. (1966) The Art of D. H. Lawrence. London: Cambridge University Press.

14. Tennyson, A. (1995) The Collected Poems of Alfred Lord Tennyson. Wordsworth: Ware.

15. Yeats, W. B. (2000) Selected Poems / Ed. by Timothy Webb. London: Penguin.

16. Yeats, W. B. (2007) A General Introduction for My Work. 1937. http:/www.questia.com/PM.qst?a=o\&d=5897046, 10:45, August 24.

17. Staton, F. Shirley (1987) Literary Theories in Praxis. University of Pennsylvania Press.

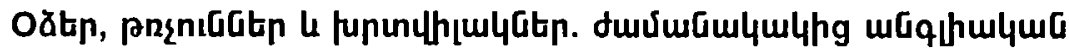

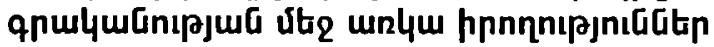

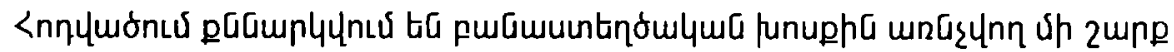

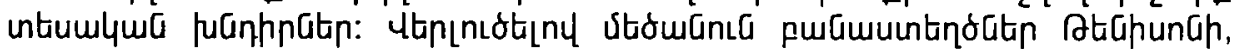

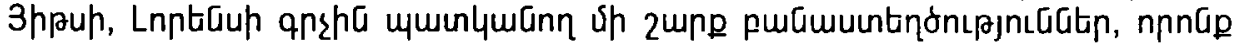

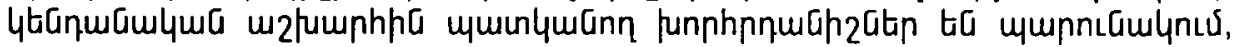

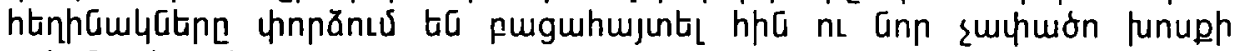

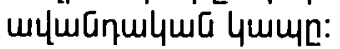

